\title{
Subcutaneous granuloma annulare for differential diagnosis of scalp nodules
}

\section{Saçı deri nodüllerinin ayırıı tanısında subkütan granüloma annulare}

๑ Sezgi Sarıkaya Solak, ๑ Nazan Akdağ, ๑ Sezin Fıçıcıoğlu, ๑ Busem Binboğa*, ๑ Nuray Can*

Trakya University Faculty of Medicine, Department of Dermatology and Venereology; *Department of Pathology, Edirne, Turkey

Keywords: Subcutaneous, deep, granuloma annulare, childhood, scalp

Anahtar Kelimeler: Subkütan, derin, granülom annulare, çocukluk çağı, skalp

\section{To the Editor,}

A 6-year-old boy presented with a 7-month history of multiple, painless, skin-colored, enlarging nodules on his scalp. The nodules appeared 3 months after a bike accident. Physical examination revealed four firm, immobile, subcutaneous nodules measuring 5-7 $\mathrm{mm}$, located on the occipital area (Figure 1a, b). He had no history of any other skin lesion or any systemic disease. Routine laboratory test results were within normal limits. Skull radiography did not show lytic lesions, calcium deposits, or calvarial invasion. Ultrasonography revealed hypoechoic solid masses located in the subcutaneous tissue (Figure 2).

Excisional biopsy of a nodule was performed. Histological examination demonstrated palisading histiocytes in

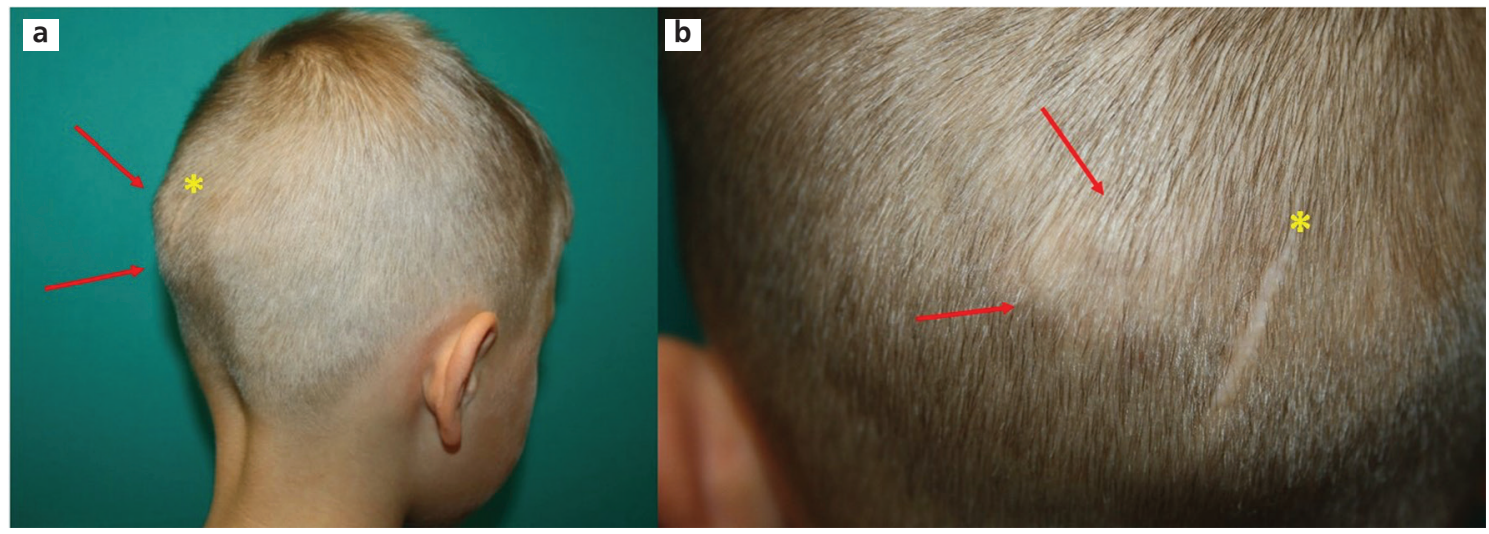

Figure 1 (a, b). Skin-colored, hard, immobile nodules on the occipital region (arrows), area of excisional biopsy (asterisk)

Yazıșma Adresi/Address for Correspondence: Sezgi Sarkaya Solak MD, Trakya University Faculty of Medicine, Department of Dermatology and Venereology, Edirne, Turkey Tel.: +90 2842357641 (1282) E-posta: sezgisarikaya@gmail.com Geliş Tarihi/Received: 15.04.2020 Kabul Tarihi/Accepted: 04.11.2020 ORCID: orcid.org/0000-0002-8572-8249

CTelif Hakkı 2021 Deri ve Zührevi Hastalıklar Derneği

Türkderm-Deri Hastalıkları ve Frengi Arșivi Dergisi, Galenos Yayınevi tarafindan basılmıștır. 


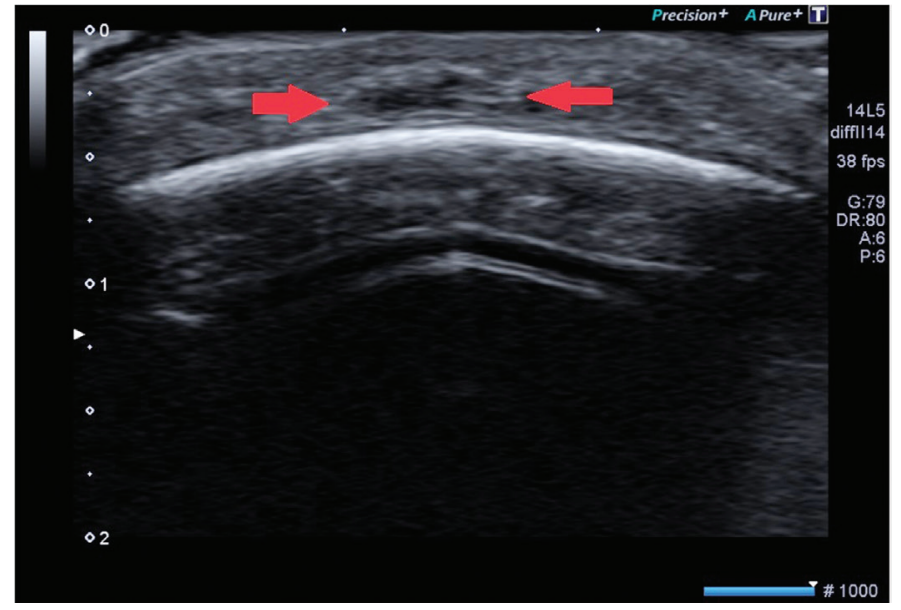

Figure 2. Ultrasound image shows a subcutaneous hypoechoic nodule (arrows)

surrounding areas of necrobiosis and mucin deposits (Figure 3a, b) In immunohistochemical study, CD68 and CD163 were positive for histiocytes (Figure 3c). The histopathological findings were compatible with subcutaneous granuloma annulare (SGA).

Clobetasol $0.05 \%$ cream and tacrolimus $0.03 \%$ ointment were applied twice daily for 2 months, but no regression was observed. Without further treatment, no changes in the nodules were observed, and five more nodules appeared on the left parietal area at 1-year follow-up. Granuloma annulare is a benign, granulomatous, inflammatory skin disorder with four main variants; localized, generalized, subcutaneous, and perforating. SGA is characterized by asymptomatic, firm nodules covered with normal skin'. It is almost exclusively seen in children and more often affect women'. SGA is most commonly located in the lower extremities, and lesions are rarely seen on the scalp ${ }^{2}$. Multiple nodules are usually seen in cases with scalp involvement $t^{3,4}$.

The etiology of SGA is unclear. No evidence support trauma, diabetes mellitus, infections such as tuberculosis, or insect bites as etiological factors. Moreover, studies have not reported an association between SGA and rheumatologic diseases ${ }^{1-4}$.

SGA may be difficult to diagnose if physicians do not take it into account in the differential diagnosis of asymptomatic scalp nodules. Benign or malignant tumors such as osteoma, lipoma, and metastasis; epidermal or dermoid cycts; various infections such as deep granulomatous infections, bacterial or fungal abscess, subcutaenous sarcoidosis, and rheumatoid nodule; and metabolic bone diseases should be considered in the comprehensive list of differential diagnosis ${ }^{1-4}$. Detailed anamnesis, physical examination, and simple laboratory tests (such as complete blood count, erythrocyte sedimentation rate, and C-reactive protein) are important to exclude trauma, malignancies, and infectious disorders. Radiography shows the lack of calcification, ossification, or bony exocytosis ${ }^{1,2}$. Ultrasonography is helpful to visualize subcutaneous hypoechoic nodules with a slightly hyperechogenic halo and without prominent vascularization, which supports the diagnosis ${ }^{5}$. Eventually, histopathologic examination is necessary for a precise diagnosis ${ }^{1,2}$. No certain effective treatment has been established for SGA. Lesions usually tend to resolve spontaneously. Given its benign and self-limiting nature, only follow-up can be proposed without treatment ${ }^{1-4}$.
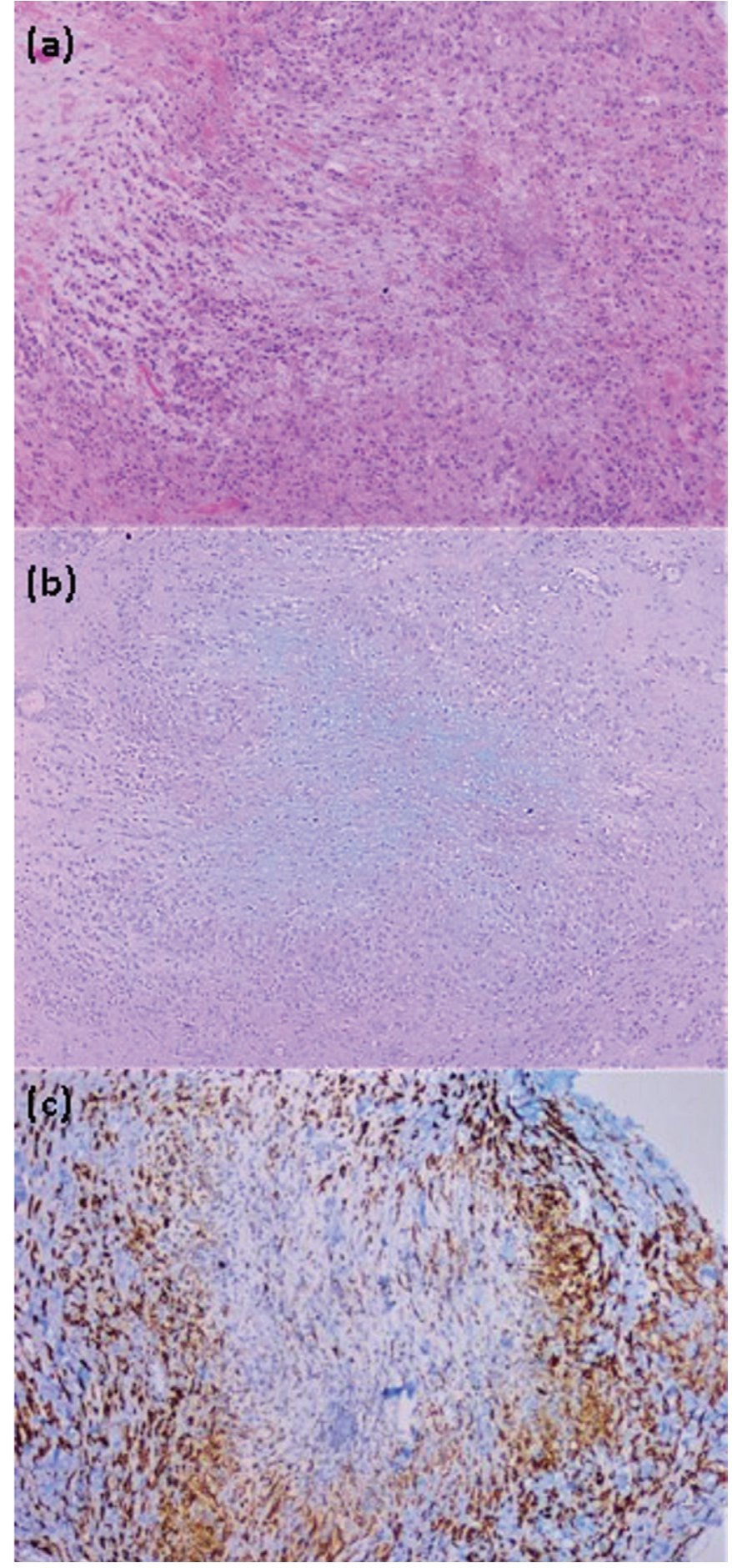

Figure $\mathbf{3}$ (a). Typical granuloma with necrobiotic center and palisading histiocytes (hematoxylin and eosin staining, x100). (b) Mucinous deposits in the central zone (periodic acid-Schiff-alcian blue, x100). (c) Palisading histiocytes around the necrobiotic center of the granuloma (CD163 staining, $\times 100)$

Herein, we present a rare case of multiple SGA of the scalp in a pediatric patient. Clinicians should consider SGA in the differential diagnosis of asymptomatic scalp nodules. Because various benign or malignant disorders may present with similar clinical findings, a biopsy is recommended to make a definite diagnosis. 


\section{Ethics}

Informed Consent: It was obtained.

Peer-review: Externally peer-reviewed.

\section{Authorship Contributions}

Surgical and Medical Practices: S.S.S., B.B., N.C., Concept: S.S.S., N.A. S.F., Design: Data Collection or Processing: S.S.S., N.A., S.F., Analysis or Interpretation: S.S.S., B.B., N.C., Literature Search: N.A., S.S.S., S.F., Writing: S.S.S., N.A., N.C.

Conflict of Interest: No conflict of interest was declared by the authors.

Financial Disclosure: The authors declared that this study received no financial support.

\section{References}

1. Felner El, Steinber JB, Weinberg AG: Subcutaneous granuloma annulare: A rewiew of 47 cases. Pediatrics 1997;100:965-7.

2. Evans MJ, Blessing K, Gray ES: Pseudorheumatoid nodule (deep granuloma annulare) of childhood: clinicopathologic features of twenty patients. Pediatr Dermatol 1994:11:6-9.

3. Neto Pimental DR, Michalany N, De Abreu MA, Alchorne M: Multiple deep granuloma annulare limited to the cephalic segment in childhood. Pediatr Dermatol 2008;25:407-8.

4. Thomas C, Morley K, Schmidt B, Hussain S: Subcutaneous granuloma annulare involving the scalp. Pediatr Dermatol 2018;35:e72-3.

5. Vázquez-Osorio I, Quevedo A, Rodríguez-Vidal A, Rodríguez-Díaz E: Usefulness of ultrasonography in the diagnosis of subcutaneous granuloma annulare. Pediatr Dermatol 2018;35:e200-1. 